\title{
Research on the Demarcation of Provincial Initial Emission Quotas and the Emissions Trading
}

\author{
Huiqin Jiang ${ }^{1, *}$, Sixiang Huang ${ }^{1}$, Yang Miao ${ }^{2}$, Jianqiang $\mathrm{Bao}^{1}$ \\ ${ }^{1}$ Zhejiang University of Technology, Hangzhou Zhejiang,310023,China \\ ${ }^{2}$ Zhijiang college of Zhejiang University of Technology,Hangzhou Zhejiang,310023,China
}

\begin{abstract}
The distribution of China's energy resources and consumption is trending to reverse. Inter-provincial cooperation from of energy transforms form transporting coal to building coal-fired power, electricity transmission and natural gas transmission. That led to the increase in total emissions and environmental pressure in energy-rich province domain, which bring pressure to completion of regional emission reduction targets. This article propose to study and explore the "fair allocation of emission rights, effective exchange of emission rights" among provinces. It has not only the theoretical value, but also practical significance. On one hand, it is based on quantify emissions accounting standards and methods to research quantify emissions accounting standards and methods to provide a quantitative basis for project-based market. On the other hand, it is the goal of scientific rationality to configure the provincial domain initial emission rights. It is scientifically setting emissions baselines according to the provincial domain resource endowment, economic level, environmental capacity, capital and technology, population quality, development potential and space differentiation characteristics. So that it can provide a reasonable basis for allowance- based market. It promotes energy conservation and carbon reduction, in order to jointly cope with climate change while promoting the energy cooperation among provinces.
\end{abstract}

\section{The phenomenon of the the energy and emission source reverse migration}

It is not balanced between the resources owned and the economic development in China. $76 \%$ coal existed in the north and northwest, but the distribution of consumption is in reverse. Over $70 \%$ consumption is distributed in the developed southeast coastal area. Recently, because of the ecological requirements of the developed southeast coastal area and the limitation of the environment capability, the transformation of energy cooperation across provinces is promoted from transporting the coal to transporting the SNG in order to realize the power transmission to coal mine and coal-fired power plant. It formed the positive output of clean energy and the backward transfer of pollution sources. ( see Picture 1)

In the "Thirteen Five" Plan, the government will designate the provinces total energy consumption "red line", especially the total coal consumption because of strengthening the haze pollution and climate change. It will put the three emissions targets of $\mathrm{CO}_{2}, \mathrm{SO}_{2}, \mathrm{NO}_{\mathrm{x}}$ directly linked to regional development assessment. To this end, problems of quantify accounting, horizontal compensation, cross transactions of the emission rights cause national and energy output provinces' attention in the process of inter-provincial energy cooperation. Which includes science and rationality of provinces initial configuration of emission rights. And market exchange and trading emission rights issues have also been academic attention. Therefore, it is a new topic that fair allocation of emission rights and effective exchange of emission rights inter-provincial cooperation. It has not only the theoretical value, but also practical significance.

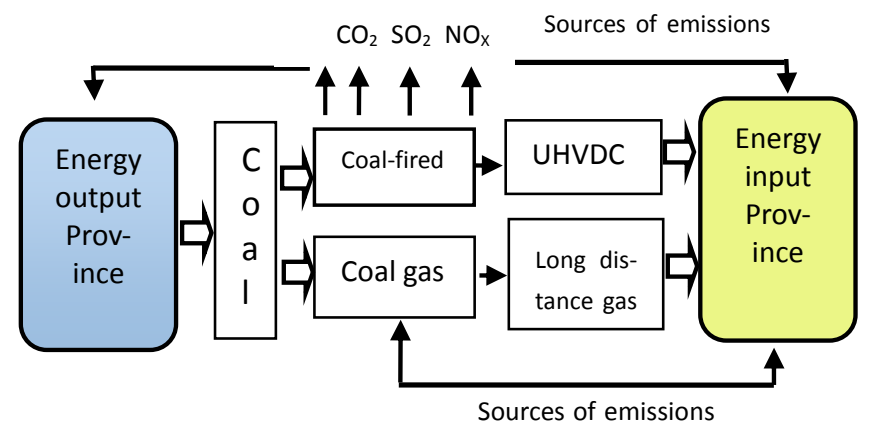

Picture1.The positive output of clean energy and the backward transfer of pollution sources.

\section{Quantitative assessment and account -ing of the Emission source reverse migration in the cooperation projects between two types of energies}

It is well known that the traditional way of energy cooperation across provinces including the arrangement of thermal power plants in energy input province and the contract with the energy-rich province to ensure the energy(electricity) supply within this area.

\subsection{The accounting of main emissions from the pithead coal-fired power plants project}

Because the pithead coal-fired power plants are set up at the edge of the coal base, they can supply the electricity to coastal power grid point to point, in order to reduce the coal transportation and release the 
Table 1:The estimated emissions of building million kilowatts coals and the impacts on the ecological environment

\begin{tabular}{|l|l|l|l|l|}
\hline & $\begin{array}{l}\text { Coal } \\
\text { consumption } \\
\text { (Ten } \\
\text { thousand } \\
\text { tons) }\end{array}$ & $\begin{array}{l}\text { The } \\
\text { emissions } \\
\text { of } \mathrm{CO}_{2} \\
\text { (Ten } \\
\text { thousand } \\
\text { tons) }\end{array}$ & $\begin{array}{l}\text { The } \\
\text { emissions } \\
\text { of } \\
\mathrm{SO}_{2} \text { (Tons } \\
\text { ) }\end{array}$ & $\begin{array}{l}\text { The } \\
\text { emissions } \\
\text { of } \\
\text { NOx(Ton } \\
\text { s) }\end{array}$ \\
\hline $\begin{array}{l}\text { The project } \\
\text { of million } \\
\text { kilowatts } \\
\text { coals }\end{array}$ & 230 & 400 & 3000 & 1200 \\
\hline $\begin{array}{l}\text { 185 million } \\
\text { kilowatts } \\
\text { (Year } \\
\text { 2015) }\end{array}$ & 42550 & 74000 & 555000 & 222000 \\
\hline
\end{tabular}

environment pressure. Based on 'the Emission standard of air pollutants for thermal power plants (GB132232011)' and 'the Provincial greenhouse gas inventory guidelines (for Trial Implementation)'(2011), the emission can be accounted in a quantitative way. The main emissions during the process of coal-fired power generation, such as $\mathrm{CO}_{2}, \mathrm{SO}_{2}, \mathrm{NO}_{\mathrm{x}}$, TSP are measured. (see Table 1).

\subsection{The major emissions accounting of Synthetic Natural Gas project}

Coal Based Synthetic Natural Gasis an energy that through coal gasification produces synthesis gas, and then after methanation process produces Synthetic Natural Gas (SNG). Synthetic Natural Gas (SNG) is a clean energy with high energy conversion rate ( up to about 50\%), which after combustion, particulate matter , $\mathrm{SO}_{2}, \mathrm{CO}$ of its release accounts for only $1 / 660,1 / 120,1 / 132$ comparing to coal combustion, coastal provinces are happy to develop.According to Environmental impact report of $1200 \mathrm{M} 3 / \mathrm{d}$ Synthetic Natural Gas(SNG) project and relevant analysis and research, plus relevant accounting methods and standards, it can be quantified accounting. We estimates $\mathrm{CO}_{2}, \mathrm{SO}_{2}$, waste and wastewater which coal-fired power generation mainly discharges preliminarily( as shown in Table 2).
Table 2. The emissions and environmental impact estimates of building 2 billion M3 / year Synthetic Natural Gas (SNG)

\begin{tabular}{|l|l|l|l|l|l|}
\hline & $\begin{array}{l}\text { Coal } \\
\text { consumpti } \\
\text { on } \\
\left(10^{4} \text { tons }\right)\end{array}$ & $\begin{array}{l}\text { Emission } \\
\text { of } \mathrm{CO}_{2} \\
\left(10^{4} \text { tons }\right)\end{array}$ & $\begin{array}{l}\text { Emissi } \\
\text { on of } \\
\mathrm{SO}_{2} \text { (to } \\
\mathrm{ns})\end{array}$ & $\begin{array}{l}\text { Ash(1 } \\
0^{4} \\
\text { tons })\end{array}$ & $\begin{array}{l}\text { Waste } \\
\text { water( } \\
10^{4} \\
\text { tons })\end{array}$ \\
\hline $\begin{array}{l}2 \text { billion } \mathrm{M}^{3} \\
/ \text { year SNG }\end{array}$ & 580 & 1580 & 4500 & 60 & 130 \\
\hline $\begin{array}{l}18 \text { billion } \\
\mathrm{M}^{3}(2015)\end{array}$ & 5220 & 14220 & 40500 & 540 & 1170 \\
\hline
\end{tabular}

Data source: WANG Xiaowu, HUA Ben, Comparison between liquefied natural gas, pipe natural gas and substitute natural gas, CIESC Journal,Vol1 60(2009),35-38

\section{Initial emission right has been the scarce environmental resources prope- rty right to each province}

On the premise of esurience that the implementation of this right wouldn't damage other public environmental rights and interests, the right of emission right refers to the right of discharging pollutants into the environment in accordance with the law, which is within the quota allocated by environmental protection administration. Like water resources and mineral resources, emission right also belongs to the public resources. The configuration of all provinces' traditional emission right has two characteristics: firstly, emission quotas is configured free of charge under the guidance of the state; secondly, emission quota is based on regional historical emissions, with the configuration method of "base + decline rate".

Table 3:The energy input of the southeast coastal economically developed provinces:

\begin{tabular}{|l|l|l|l|l|l|l|l|}
\hline $\begin{array}{l}\text { Provinc } \\
\mathrm{e}\end{array}$ & $\begin{array}{l}\text { Percen } \\
\text { t of } \\
\text { energy } \\
\text { self- } \\
\text { suffici } \\
\text { ency( } \\
\%)\end{array}$ & $\begin{array}{l}\text { Inpu } \\
\text { tting } \\
\text { pow } \\
\text { er } \\
\left(10^{4}\right. \\
\mathrm{KW} \\
\mathrm{h})\end{array}$ & $\begin{array}{l}\text { Input } \\
\text { ting } \\
\text { coal } \\
\text { gas } \\
(108 \\
\mathrm{M}^{3}\end{array}$ & $\begin{array}{l}\text { Emis } \\
\text { sion } \\
\text { redu } \\
\text { ction } \\
\text { of } \\
\mathrm{CO}_{2}\end{array}$ & $\begin{array}{l}\text { Emis } \\
\text { sion } \\
\text { reduc } \\
\text { tion } \\
\text { of } \\
\mathrm{SO}_{2}\end{array}$ & $\begin{array}{l}\text { Emis } \\
\text { sion } \\
\text { redu } \\
\text { ction } \\
\text { of } \\
\mathrm{NOx}\end{array}$ & $\begin{array}{l}\text { Emissio } \\
\text { n right } \\
E-\mathrm{CSN}\end{array}$ \\
\hline $\begin{array}{l}\mathrm{A}_{1} \text { (Shan } \\
\text { ghai) }\end{array}$ & 0.65 & $\mathrm{X}_{1}$ & $\mathrm{Y}_{1}$ & $E-\mathrm{T}_{1}$ & $E-\mathrm{L}_{1}$ & $E-\mathrm{D}_{1}$ & $E-\mathrm{CSN}_{1}$ \\
\hline $\begin{array}{l}\mathrm{A}_{2} \text { (Zhej } \\
\text { iang) }\end{array}$ & 3.9 & $\mathrm{X}_{2}$ & $\mathrm{Y}_{2}$ & $E-\mathrm{T}_{2}$ & $E-\mathrm{L}_{2}$ & $E-\mathrm{D}_{2}$ & $E-\mathrm{CSN}_{2}$ \\
\hline $\begin{array}{l}\mathrm{A}_{3} \text { (Jian } \\
\text { gsu) }\end{array}$ & 12.7 & $\mathrm{X}_{3}$ & $\mathrm{Y}_{3}$ & $E-\mathrm{T}_{3}$ & $E-\mathrm{L}_{3}$ & $E-\mathrm{D}_{3}$ & $E-\mathrm{CSN}_{3}$ \\
\hline $\begin{array}{l}\mathrm{A}_{4} \text { (Gua } \\
\text { ngdong) }\end{array}$ & 22.2 & $\mathrm{X}_{4}$ & $\mathrm{Y}_{4}$ & $E-\mathrm{T}_{4}$ & $E-\mathrm{L}_{4}$ & $E-\mathrm{D}_{4}$ & $E-\mathrm{CSN}_{4}$ \\
\hline $\begin{array}{l}\mathrm{A}_{5} \text { (Fujia } \\
\text { n) }\end{array}$ & 33.2 & $\mathrm{X}_{5}$ & $\mathrm{Y}_{5}$ & $E-\mathrm{T}_{5}$ & $E-\mathrm{L}_{5}$ & $E-\mathrm{D}_{5}$ & $E-\mathrm{CSN}_{5}$ \\
\hline $\begin{array}{l}\mathrm{A}_{6} \text { (Shan } \\
\text { dong) }\end{array}$ & 46.8 & $\mathrm{X}_{6}$ & $\mathrm{Y}_{6}$ & $E-\mathrm{T}_{6}$ & $E-\mathrm{L}_{6}$ & $E-\mathrm{D}_{6}$ & $E-\mathrm{CSN}_{6}$ \\
\hline $\mathrm{A}_{\mathrm{i}}$ & & $\mathrm{X}_{\mathrm{i}}$ & $\mathrm{Y}_{\mathrm{i}}$ & $E-\mathrm{T}_{\mathrm{i}}$ & $E-\mathrm{L}_{\mathrm{i}}$ & $E-\mathrm{D}_{\mathrm{i}}$ & $E-\mathrm{CSN}_{\mathrm{i}}$ \\
\hline
\end{tabular}

Remarks: $\mathrm{CSN}_{\mathrm{i}}$ represents the overall amount emission of $\mathrm{CO}_{2}, \mathrm{SO}_{2} \mathrm{NO}_{\mathrm{X}}$ of the special energy inputting provinces. All of $\mathrm{CSNi}$ are national binding emission reductions except $\mathrm{CO}_{2}$. 
Suppose, energy inputting province is $A_{i}$, energy outputting province is $\mathrm{B}_{\mathrm{i}}$, during the provincial energy cooperation, regarding Coal power generation and coal gasification as the research object (as shown in table three, table 4), the output power of province $\mathrm{Bi}$ is $\mathrm{X}_{\mathrm{i}}$; gas transmission volume is $\mathrm{Y}_{\mathrm{i}}$; according to the related emissions accounting standards and methods:

(A)by simplifying and quantifying to the total emission of province $\mathrm{B}_{\mathrm{i}}$ 's energy output of $\mathrm{X}_{\mathrm{i}}$ and $\mathrm{Y}_{\mathrm{i}}$ :

$$
E_{B i}=\sum\left(x_{i}^{*} E F_{i, k}+y_{i} * E F_{i, k}\right)=\sum\left(E_{t i}+E_{l i}+E_{d i}\right)
$$

(B)Thereinto, $\mathrm{EB}_{\mathrm{i}}$ stands for the reverse emissions of province $\mathrm{B}_{\mathrm{i}}$ 's output power and gas volume;

EF: emission factor $(\mathrm{kg} / \mathrm{KWh})$;

$\mathrm{X}_{\mathrm{i}}$ : the output power of $\mathrm{Bi}(\mathrm{KWh})$;

I: the type of fuel;

$\mathrm{K}$ : the type of power generation technology.

(C)With the same emission accounting standards and methods of province $B_{i}$, convert province $A_{i}$ 's clean energy input "to reduce emissions":

$E_{A i}=\sum\left(X_{i} * E F_{i, k}+Y_{i} * E F_{i, k}\right)=\sum\left(E_{T i}+E_{L i}+E_{D i}\right)$

(D)The nationally initial emission quota of energy outputting province $\mathrm{B}_{\mathrm{i}}$ is E-csni; when changing the energy cooperation mode, it turns to be $+\mathrm{EB}_{\mathrm{i}}$

The nationally initial emission quota of energy inputting province $\mathrm{A}_{\mathrm{i}}$ is $\mathrm{E}-\mathrm{CSN}_{\mathrm{i}}$; when changing the energy cooperation mode, it turns to be $-\mathrm{EA}_{\mathrm{i}}$

(E)The emission reducing task of province $B_{i}$ is large: $\mathrm{E}(\mathrm{B})=\mathrm{E}-\operatorname{csn}_{\mathrm{i}}{ }^{*}\left(1-\beta \mathrm{B}_{\mathrm{i}}\right)+\mathrm{EB}_{\mathrm{i}} \beta \mathrm{B}_{\mathrm{i}}$ : theemission reducing rate (national requirements)

Province $A_{i}$ takes a new path of emission reduction: $E(A)$ $=\mathrm{E}-\mathrm{CSN}_{\mathrm{i}}{ }^{*}\left(1-\beta \mathrm{A}_{\mathrm{i}}\right)-\mathrm{EA}_{\mathrm{i}} \beta \mathrm{A}_{\mathrm{i}}$ : the emission reducing rate (national requirements)

In order to construct an emissions trading market system of the provincial inter domain, the rationality and fairness of the baseline of each provincial initial emission quota turns out to be the basic scientific problem. Whether it is reasonable of the initial emission quota of energy inputting province $\mathrm{B}_{\mathrm{i}}$ ( E-csni ) and the initial emission quota of energy inputting province $A_{i}$ ( E-CSN ), it may needs further and deeper research to figure out the scientific basis (resource endowment $(\alpha)$, economic level $(\delta)$, environmental capacity (ETA), financial capital (f), science and Technology Foundation $(\mu)$, the quality of the population $(\mathrm{P})$, the development potential of $(\lambda)$ and regional $(\theta)$ etc.). At the same time, we also need to create a fair market environment for the development of the provincial emission rights trading, to provide a public platform to solve the structural contradiction of the "energy and emissions reverse migration" during the provincial energy cooperation. From the national perspective, Western energy bases shifting from coal to gas transmission, brought the problem of "emission source reverse migration", but is good to relief Eastern environmental pressure and coal pressure. By the mode and mechanism of marketing emission trading, the state can guide the economic developed province to change from the energy corporation to industry corporation and environmental protection corporation, to bring capital, technology, talent for energy output provinces, in order to promote the development of low carbon green circulation.

\section{Developing country's two types and three kinds of Emissions-trading market}

Taking international responsibility of climate change is GOC's promise. So developing allowance-based and project-based emissions trading market .While developing this two kinds of trading mode, system and mechanism are very important. First, developing two types of emissions-trading market which called allowance-based and project-based. Second, developing three kinds of emissions-trading market which contain $\mathrm{CO}_{2}, \mathrm{SO}_{2}, \mathrm{NO}_{\mathrm{x}}$. These are called country's two types and three kinds of Emissions-trading market. The later belongs to the national binding's emission. Processing separately $\mathrm{CO}_{2}, \quad \mathrm{SO}_{2}, \quad \mathrm{NO}_{\mathrm{x}}$ trading's issue through researching three kinds of emission's type pattern, quantity, accounting method, verify method, inspect method.

\subsection{Allowance-based emission trading market mode}

Allowance-based emission trading market mode is similar to Joint Implemented in Kyoto Protocol,energy input province $A_{i}$ helps output province $B_{i}$ to build emission project, and sell the emission reduction unit to deduct the assigned amount units or charge against the parts of units that clean energy forward output which is part of pollution source reverse remove's unit. According to emissions trading markets, certifying emission reduction units and getting China's approval. At present, the energy input province $A_{i}$ have reduce the energy conservation and emission reduction's marginal efficiency, but the emission reduction's cost rise.Transprovincial emission reduction's allowance-based market and project-based market can reduce emission reduction's cost and increase efficiency so it can bring about country's emission reduction's goal .

Base in country layer's emission rights' exchange and trading's top layer design and institutional arrangement, it can solve government and market's fairness and efficiency's problem radically. For example, giving up selling the emission rights $B_{i}$ or making sure the buyer $A_{i}$ subject, trading format, pricing institution, settlement bargain, and also including emission allowance's granting, emission units' certificating, emission online monitor. These can boost transprovincial emission rights' trading scientization, rationalization and standardization.

\subsection{Base in trans-provincial energy cooperation project's emission rights trading mode.}

Energy project certified emission amount units can be exchanged and traded separate in two parts. One is emission rights trading, Energy output province $\mathrm{B}_{\mathrm{i}}$ can sell all or parts of emission units in country emission rights trading market. And energy input province $A_{i}$ can buy all or parts of emission units. They can negotiate the price or use the market mechanism. After the trade, energy output province $B_{i}$ admit and except emission source remove reverse, and energy input province $A_{i}$ get 
the Emission Reduction Units because of buying the emission rights. The other is emission rights exchange. Energy input province $A_{i}$ exchange the Certified Emission Amount Units with energy output province $B_{i}$ that is the energy cooperation partner. Those units are reckoned in province $A_{i}$ 's emission gross. According to development situation, emission reduction's tendency, market changing, overall trend each province will make policy choice and market judge in emission rights dealing or exchange trading market.

Developing trans-provincial emission rights trading market's micro foundation is country need formulate the accounting standard and method in emission reduction project or something about energy project. And certificating the project's Certified Emission Amount Units for certificating, measuring, computing the emission units in trans-provincial's emission rights trading or exchanging.

Each province's emission rights deal with the emission source remove problem through the government policy administration and market trading institution. Each province's policy administration's is emission initial configuration, trans-provincial's emission rights trading or exchanging is market mechanism, the goal is to control emission gross ,optimize emission rights' configuration and increase the emission efficiency. Trans-provincial energy cooperation corresponding to two types and three kinds(two types are allowance-based and project-based emissions trading market, three emission mode contains
$\mathrm{CO}_{2}, \mathrm{SO}_{2}, \mathrm{NO}_{\mathrm{x}}$ )emission trading market. New mode include two types and three kinds emission rights market management institution, running system and the third party certification, which containing emission certification's granted, certified emission amount units, trading law system. Also including emission trade rights' trade program, trade mode, pricing institution, clearance and settlement, emission online monitor's setting between each province. So that giving the new thought in the innovation of the trans-provincial in emission trading market system.

Table 4:The energy output of the five largest energy bases

\begin{tabular}{|c|c|c|c|c|c|c|c|}
\hline & Province & $\begin{array}{l}\text { Outputti } \\
\text { ng power } \\
10^{4} \mathrm{KWh}\end{array}$ & $\begin{array}{l}\text { Outputtin } \\
\text { g coal } \\
\text { gas } \\
10^{8} \mathrm{M}_{3} \\
\end{array}$ & $\begin{array}{c}\text { Emission } \\
\text { reduction } \\
\text { of } \mathrm{CO}_{2}\end{array}$ & $\begin{array}{c}\text { Emission } \\
\text { reduction } \\
\text { of } \mathrm{SO}_{2}\end{array}$ & $\begin{array}{l}\text { Emission } \\
\text { reduction of } \\
\mathrm{NO}_{\mathrm{x}}\end{array}$ & $\begin{array}{c}\text { Emission right } \\
\text { E-csni }\end{array}$ \\
\hline $\begin{array}{c}\text { Shanxi energy } \\
\text { base }\end{array}$ & B1(Shanxi) & $\mathrm{x}_{1}$ & $\mathrm{y}_{1}$ & E- $t_{1}$ & $E-l_{1}$ & E-d $d_{1}$ & E-csn 1 \\
\hline $\begin{array}{c}\text { Region of Inner } \\
\text { Mongolia } \\
\text { energy base }\end{array}$ & $\begin{array}{l}\text { B2(Inner } \\
\text { Mongolia) }\end{array}$ & $\mathrm{x}_{2}$ & $\mathrm{y}_{2}$ & E- $t_{2}$ & $\mathrm{E}-\mathrm{l}_{2}$ & E-d1 $1_{2}$ & E-csn 2 \\
\hline $\begin{array}{c}\text { Xinjiang energy } \\
\text { base }\end{array}$ & B3(Xinjiang & $\mathrm{x} 3$ & y3 & E-t3 & $\mathrm{E}-\mathrm{l}_{3}$ & E-d $d_{3}$ & E-csn3 \\
\hline \multirow[t]{3}{*}{ Erdos basin } & B4(Shannxi) & $\mathrm{x} 4$ & y4 & E-t4 & E- $\mathrm{l}_{4}$ & E-d $d_{4}$ & E-csn4 \\
\hline & $\mathrm{B}_{5}$ (Ningxia) & $\mathrm{X}_{5}$ & $\mathrm{y}_{5}$ & $E-\mathrm{t}_{5}$ & $E-1_{5}$ & $E-\mathrm{d}_{5}$ & $E-\operatorname{csn}_{5}$ \\
\hline & $\mathrm{B}_{6}$ (Gansu) & $\mathrm{x}_{6}$ & $\mathrm{y}_{6}$ & $E-\mathrm{t}_{6}$ & $E-1_{6}$ & $E-\mathrm{d}_{6}$ & $E-\operatorname{csn}_{6}$ \\
\hline \multirow{4}{*}{$\begin{array}{l}\text { The southwest } \\
\text { energy base }\end{array}$} & $\mathrm{B}_{7}($ Guizhou & $\mathrm{x}_{7}$ & $\mathrm{y}_{7}$ & $E-\mathrm{t}_{7}$ & $E-\mathrm{l}_{7}$ & $E-\mathrm{d}_{7}$ & $\operatorname{Ecsn}_{7}$ \\
\hline & $\mathrm{B}_{8}$ (Yunnan) & $\mathrm{X}_{8}$ & $\mathrm{y}_{8}$ & $E-\mathrm{t}_{8}$ & $E-1_{8}$ & $E-\mathrm{d}_{8}$ & $E-\operatorname{csn}_{8}$ \\
\hline & $\mathrm{B}_{9}($ Sichuan $)$ & $\mathrm{X}_{9}$ & $\mathrm{y}_{9}$ & $E-\mathrm{t}_{9}$ & $E-1_{9}$ & $E-\mathrm{d}_{9}$ & $\operatorname{Ecsn}_{9}$ \\
\hline & $\mathrm{B}_{\mathrm{i}}$ & $\mathrm{x}_{\mathrm{i}}$ & $\mathrm{y}_{\mathrm{i}}$ & $E-\mathrm{t}_{\mathrm{i}}$ & $E-1_{\mathrm{i}}$ & $E-\mathrm{d}_{\mathrm{i}}$ & $E-\operatorname{csn}_{\mathrm{i}}$ \\
\hline
\end{tabular}

Remarks: $\mathrm{CSN}_{\mathrm{i}}$ represents the overall amount emission of $\mathrm{CO}_{2}, \mathrm{SO}_{2} \mathrm{NO}_{\mathrm{X}}$ of the special energy inputting provinces. All of CSN $\mathrm{C}_{\mathrm{i}}$ are national binding emission reductions except $\mathrm{CO}_{2}$. 


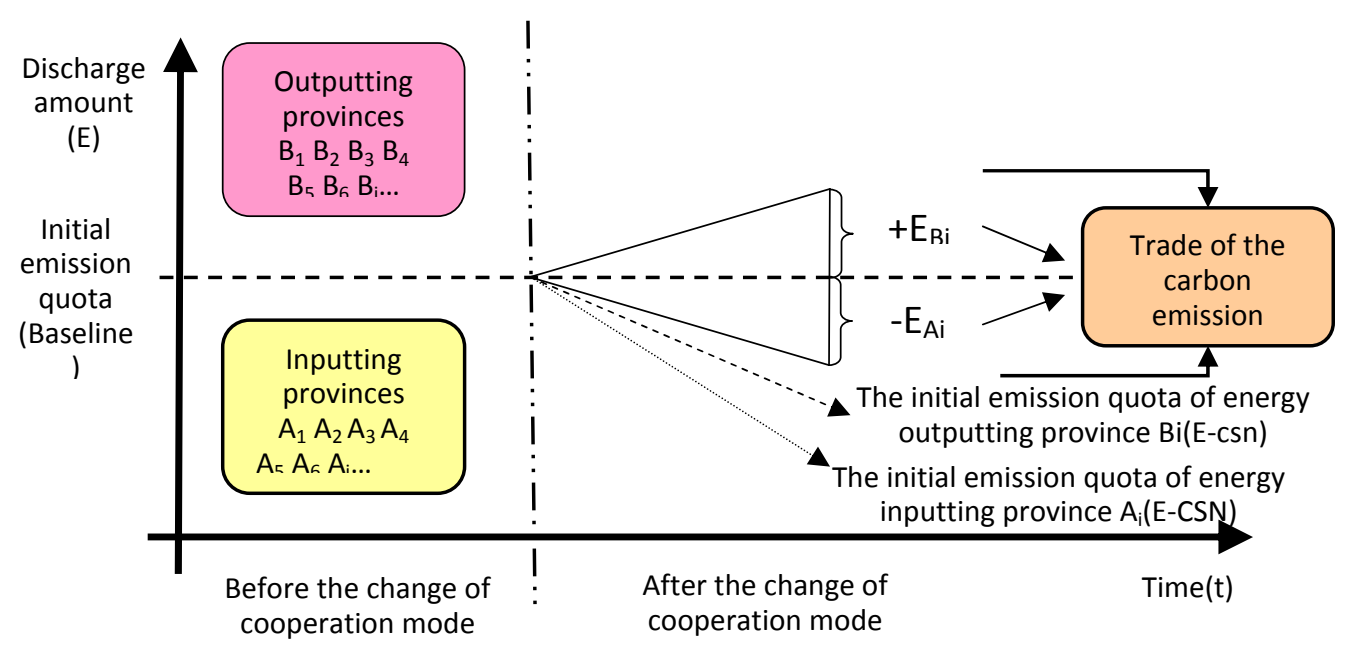

Picture 2:Diagram of the provincial emission rights trading

\section{Acknowledgements}

This work is supported by grant Nos.LQ15G030008 of Natural Science Foundation of Zhejiang Province and Humanities \& social sciences fund of Ministry of Education under grant Nos.12YJC630074 and Nos.14YJCZH109, and also is supported by Pre-research fund from Zhejiang University of Technology.

\section{References}

[1] Schennach S M. The economics of pollution permit banking in the context of title IV of the 1990 clean air act amendments [J]. Journal of Environmental Economics and Management, 2000, 40(3):189-210.

[2] IPCC. Kyoto Protocol, UK: Cambridge University Press.2006

[3] IPCC ( Intergovernmental Panel on Climate Change ).Climate Change 2007-The Physical Science Basis.Contribution of Working Group I to the Fourth Assessment Report of the IPCC[R]. Cambridge: Cambridge University Press, 2007.

[4] Goeree , J . et al (2010), “An experimental study of auctions versus grandfathering to assign pollution permit s", Journal of European Economic Association $8(2$ - 3) :514 - 525.

[5] Sovacool , B. K. (2010) ,"Building umbrellas or Arks? Three alternatives to carbon credit s and off set s", he Electricity Journal 23 (2) :29 - 40.

[6] Betz, R. et al (2010) ,"Auctioning greenhouse gas emissions permit s in Australia", Australian Journal of Agricultural and Resource Economics 54 (2) :219 - 238.

[7] ZHANG Sifeng, ZHANG Yan, TANG Min. Construction and application of evaluation model for restoration compensation for ecological damage in the exploitive zone of coal mines[J].Research of Environmental Sciences, 2012, 25( 1) : 116-124.
[8] WANG Xiaowu, HUA Ben, Comparison between liquefied natural gas, pipe natural gas and substitute natural gas, CIESC Journal, Vol1 60(2009),35-38

[9] Babiker M.H, Climate change policy, market structure, and carbon leakage, Journal of International Economics 65, 2005(2),126-131

[10]Costanza R. D’Arge R, Groot R, eta1. The value of the world's ecosystem services and natural Capital[J],Nature, 1997,387: 233 -240.386: 253-260.

[11]EU. Integrated pollution prevention and control ( IPPC) reference document on best available techniques in the large combustion plants[R].Brussels: European Union, 2006. 